\title{
Studies on the Flavonoids from the Fresh Seedling of Safflower (Carthamus tinctorius L.) ベニバナ芽生えに含まれるフラボノイドの分離および化学構造
}

Takao HONMA, Akira NARUSE, Yasuhiro MATSUHISA

Department of Industrial Chemistry, School of Engineering, Tokai University, 1117, Kitakaname, Hiratsuka-shi, 259-12, JAPAN. TEL. 0463-58-1211.

(Recieved 9, November 1989 , Accepted 31, May 1990)

Luteolin-7-glucoside have been isolated from the fresh seedling of Safflower (Carthamus tinctrius L.). The chemical structure of Luteolin-7-glucoside as

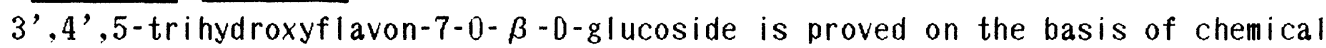
and spectroscopical evidences.

Key words; carthamus tinctrius, fresh seedling, flavonoids isolation, luteolin7-0-glucoside

\section{1. 緒言}

ベニバナ( Carthamus tinctrius L.)は、植物分 類学上ききょう目、きく科(Compositae)に位置し、 古来より紅の製造原料抄よび生菜等に広く用いられ ている。

ベニバナのフラボノイド類に関する研究は、古 く1844年 Preisser 1)に始り多くの報告があるが、 それらの研究は筒花状の黄色および赤色色素の研究 に集中し、筒花状以外でベニバナの葉を材料とした 研究は、1960年中沖、森田ら 2）の報告を除いて他 に見られない。

著者らは、カルタミン合成醉素の分離をベニバ ナ芽生えを材料として行った実験の際 3)、この幼 植物中に数種のフラボノイド類の存在を確認した。 本研究では、ベニバナを発芽させ 1 週間以内の芽生 えを材料として温メタノールでフラボノイド類を抽 出し、二次元ペーパークロマトグラフィーを行った ところ 10 種類のフラボノイド類を確認することが できた。その中で、 $\mathrm{NH}_{3} / \mathrm{UVT}$ 下゙黄色の発色をするク ロマトグラムをSLF-9 と仮称し、それを単離、その 化学構造を明らかにしたので報告する。

2. 方法

2-1.ベニバナ種子の芽生え

国産ベニバナ（最上ベニバナ）種子を一晩流水 に浸溑し、1000倍に希积したウスプルン液で約一時 間消毒した後、湿らしたVermiculite 上にまき、暗 所 $\left(28^{\circ} \mathrm{C}\right)$ で発芽させた。 $5 \sim 7$ 日間で長さ平均 $4 \mathrm{~cm}$
に達した暗所発芽体を本実験に用いた。 $2-2$. フラボノイド類の抽出、分離

暗所発芽体 $5.3 \mathrm{~kg}$ を温 $70 \%$ ×タノールに浸漬し メ夕ノール抽出物を濃縮後、n一へキサン洗浄を行っ た。ついでnーブタノール抽出を 2 回行い、下層を謴 縮し、Polyvinyl polypyrrolidone(以下PVPと略す) にフラボノイド類を吸着させ、糖その他を水で展開 後、70\%メタノールでフラボノィド類を溶出させた。 さきのnーブタノール抽出物とPVP カラム溶出物を濃 縮後セルロースカラムクロマトグラフィー( $7 \times 150$ $\mathrm{cm}$ ）を用い展開溶媒n-ブタノール：酢酸：水 $=4$ : $1: 2$ (vol.比)で分離精製を行った。

得られたSLF-9 分画を濃縮後メタノールで再結 晶を 2 回行い、融点 $235 \sim 238^{\circ} \mathrm{C}$ の結晶 $44.4 \mathrm{mg}$ を得た。 $2-3$. SLF -9 の加水分解

SLF-9 $10 \mathrm{mg} 2 \mathrm{~N}$ - 塩酸 $5.0 \mathrm{mI}$ を加え、70分間摆 流加熱し、冷却後遠心分離に上り得られた黄色沈澱 物を充分に水洗し、メ夕ノールからの再結晶を繰り 返し、SLF-9 Aglycone $5.1 \mathrm{mg}$ (融点 $326 \sim 327^{\circ} \mathrm{C}$ ) を 得た。遠心分離上澄液は中和し、減圧漕縮乾固し、 メ夕ノールを加え不溶物をろ別し、万液を減圧濃縮 後デシケーターにて充分乾燥させ、糖の同定のため の試料とした。

\section{3. 結果および考察}

3-1.SLF-9 のIR吸収スペクトル

SLF -9 は融点 $235 \sim 238^{\circ} \mathrm{C}$ の黄色粉末結晶、 SLF-9 Aglycone は融点 $326 \sim 327^{\circ} \mathrm{C}$ の黄色針状の結 
Table.1. UV spectral data for SLF-9 and SLF-9 Aglycone

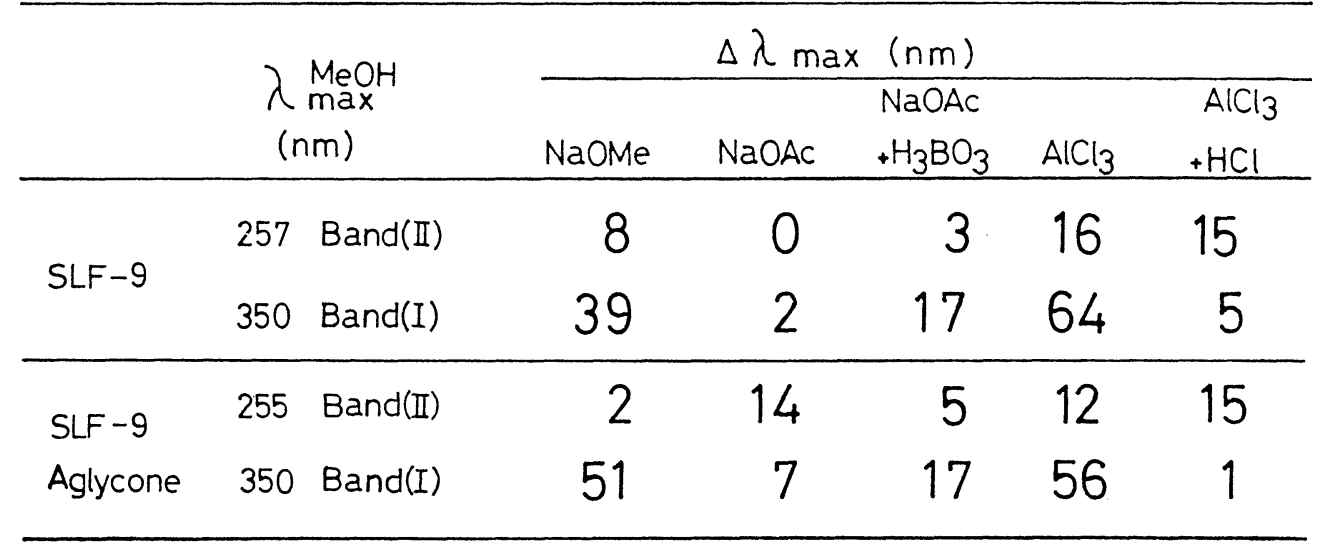

晶であった。

SLF-9 のIR吸収スペクトルでの各官能基の伸縮 振動 $v_{\max }\left(\mathrm{cm}^{-1}\right)$ は : $3400,2950,2900,1655,1605$, 1495,1440,1260,1175,1070,840であり、SLF-9 AgIyconeのIR吸収スペクトル $\nu_{\max }\left(\mathrm{cm}^{-1}\right)$ は : 3370 . $1650,1605,1505,1440,1360,1258,1165,840$ であった。 いずれもフラボノイド骨格に特徽的な共役カルボニ ル伸縮振動、また芳香族骨格振動の吸収が見られた。

3-2.SLF-9 のUV吸収スベクトルと

マススペクトル（MSスペクトル）

SLF-9 のメタノール溶液でのUV吸収スペクトル の吸収極大值 $\lambda_{\max }(\mathrm{nm})\left(\begin{array}{ll}\log \varepsilon & \varepsilon\end{array}\right)$ は、254(4.61),350 (4.59)、またSLF-9 Aglyconeの $\lambda_{\max }(\mathrm{nm})(\log \varepsilon)$ は $255(4.40), 350(4.44)$ であり、450nm 以上に吸収を もたない。これは一般のフラボン骨格を有する B 環 を含むシンナモイル系を主体とするBand I 280〜 $400 \mathrm{~nm} 、 \mathrm{~A}$ 環のベンゾイル系に由来するBand II $240 \sim 280 \mathrm{~nm}$ に2つの吸収極大をもつことに一致して いる 4)。

Table. 1 にNaOAc, NaOMe, $\mathrm{AlCl}_{3}$ 等を添加したと きのSLF-9 およびSLF-9 AglyconeのUV吸収スペクト ルの結果を示した。まず、NaOMe を少量加えて直ち に測定したときは、SLF-9で39nm、SLF-9 Aglycone で $51 \mathrm{~nm}$ 長波長シフトし、さらに添加ししばらく放置 するといずれの吸収もBand II の吸収が減少した。こ れは B 環の 4 '位、または 3 '、4 位に O H 基の存 在を推定させる。つぎに、NaOAC を添加した場合、 SLF-9 はBand II 変化なくBand I $22 \mathrm{~nm}$ のシフトが 見られ、SLF-9 AglyconeではBand II そ14nm、Band I に $7 \mathrm{~nm}$ の長波長シフトが見られたことにより、

SLF-9 Aglyconeの 7 位にO H 基の存在が推定される したがってSLF-9 では糖の置換位置が 7 位と推定す ることができる。さらに $\mathrm{NaOAC}+\mathrm{H}_{3} \mathrm{BO}_{3}$ 添加の場合、 SLF-9、SLF-9 Aglycone 両者ともBand I が17nm長波 長シフトすることより、B 環上にOージヒドロキシ
グルーブがあることが予想される。 $\mathrm{AlCl}_{3}$ を添加し た場合、SLF-9 ではBand I が64nm、Band II が $16 \mathrm{~nm}$ 長 波長シフトし、 $\mathrm{AlCl}_{3} / \mathrm{HCl}$ を添加した場合Band II に $15 \mathrm{~nm}$ の長波長シフトが見られることより B 環上の 3 ’、4 位に $\mathrm{OH}$ 基の存在が、また $\mathrm{A}$ 環上の 5 位に $\mathrm{O} \mathrm{H}$ 基の存在が推定される。SLF-9 Aglyconeに扔い ても同程度のシフトが見られるので隣接水酸基の存 在が考えられる 5)。

SLF-9 AglyconeのMSスペクトル分子イオンピー クの值より $\mathrm{C}_{15} \mathrm{H}_{10 \mathrm{O}_{6}}$ (286)の分子式をむつものと 推定した。MSスペクトルにおいてA 環に由来する

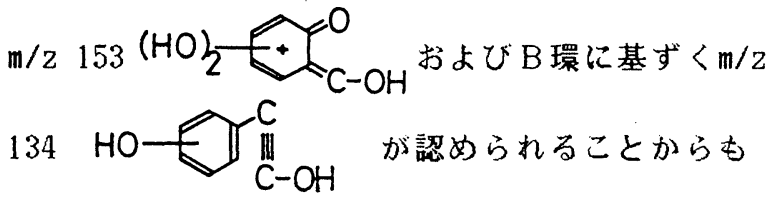

$\mathrm{B}$ 環上 $3{ }^{\prime} 、 4$ 位の水酸基の存在が予想される。 $3-3$. 結合糖の同定

結合糖はセルロースTLC（展開溶媒 vol。比/ $\mathrm{n}$ ーブタノール：酢酸：水=4:1：2、メタノー ル：ピリジン：水：酢酸 $=6: 6: 4: 1 、 \mathrm{i}-$ フ タノール：ピリジン：水：酢酸=12:6:4:1 $\mathrm{i}$ 一ブロパノール：ビリジン：水：酢酸 $=8: 8$ : $4: 1$ 、発色唷/アニリンフタル酸）と、TMS 化し たガスクロマトグラフィー分析の結果、いずれの場 合もD-glucose を示唆する結果となった。 3-4. SLF-9 Aglyconeの ${ }^{1} H$-NMRスペクトル

Fig-1 にSLF-9 Aglyconeの ${ }^{1} H$-NMRスペクトルを 示す。7.4 6.0ppm に1 個の孤立プロトンを含む 6 個のベンゼン環上のプロトンが、また低磁場に4個 のOHプロトンが認められる。これらのプロトンは これまでの事実と合わせて次のように帰属できる。 すなわち、最も低磁場側 $12.98 \mathrm{ppm}(1 \mathrm{H}, \mathrm{s})$ は 4 位の力 ルボニル基と水素結合をしている 5 位の $\mathrm{OH}$ ブロト ン、 $10.83 \mathrm{ppm}(1 \mathrm{H}, \mathrm{s})$ は 7 位 $\mathrm{OH} 、 9.92 \mathrm{ppm}(1 \mathrm{H}, \mathrm{s})$ は 
4'位 O H、9.41ppm(1, $\mathrm{s})$ は 3 '位 O H、7.41 ppm $(1 \mathrm{H}, \mathrm{d})$ は $2^{\prime}$ 位 C Hブロトンでメ夕位の 6 '位のプ ロトンとカップリング $(\mathrm{J}=2.3 \mathrm{~Hz})$ して二重線となり $7.40 \mathrm{ppm}(1 \mathrm{H}, \mathrm{dd})$ は 6 ，位の C Hプロトンで、磷接す る 5 ，位のブロトンとカップリング $(\mathrm{J}=8.4 \mathrm{~Hz})$ し、 さらにメ夕位の 2 '位のブロトンともカップリング $(\mathrm{J}=2.3 \mathrm{~Hz}) し \tau 4$ 本に分れている。6.89ppm(1H,d) は 5 ’位のブロトンで隣接する 6 ’位のプロトンと カップリング $(\mathrm{J}=8.4 \mathrm{~Hz})$ し二重線となっている。

$6.67 \mathrm{ppm}(1 \mathrm{H}, \mathrm{s})$ は他のプロトンの影䇾を受忛ていな い3 位 C H プロトンで、6.45ppm(1H,d) は 6 位 C H プロトン $6.19 \mathrm{ppm}(1 \mathrm{H}, \mathrm{d})$ とカップリング $(\mathrm{J}=2.0 \mathrm{~Hz})$ している 8 位 C Hプロトンであり、それぞれ二重線 となっている。

3-5. SLF-9 とSLF-9 Aglyconeの

${ }^{13} \mathrm{C}$-NMR スペクトル

SLF-9 Aglyconeの ${ }^{13}$ C-NMR スペクトル(Fig.2) では15本のシグナルが見られ、この数は分子式 $\mathrm{C}_{15} \mathrm{H}_{10} \mathrm{O}_{6}$ のフラボノイド骨格の炭素数に一致す る。これらのシグナルは 9 本の一重線と 6 本の二重
線とからなっている。

SLF-9(Fig.3)とSLF-9 Aglyconeの ${ }^{13} \mathrm{C}-\mathrm{NMR}$ スペ クトルのシグナルの㷌属は、構造の類似したフラボ ノイド配糖体およびそれらの誘導体のデータを参考 に行った。帰属の結果は、Table.2 に示す通りであ る。

以上の結果より、SLF-9 Aglyconeは3’,4’,5.7 - tetrahydroxyflavoneすなわち Luteolin と一致し SLF-9 はFig.4に示したLuteolin-7-0-0-Glucoside であると推定した。

\section{4. 結言}

1、植物からのフラボノイド類の単離操作の過 程において、PVPの吸着クロマトグラフィーを行 なうことにより、糖類その他不要物を容易に取り除 くことができ、目的物であるフラボノイドを容易に 単離することが可能になった。

2、ベニバナ(Carthamus tinctrius L.)の芽生 え中に、成葉中に見いだされているLuteolin-7-0-D -glucosideの存在を明らかとした。なお、暗所発芽

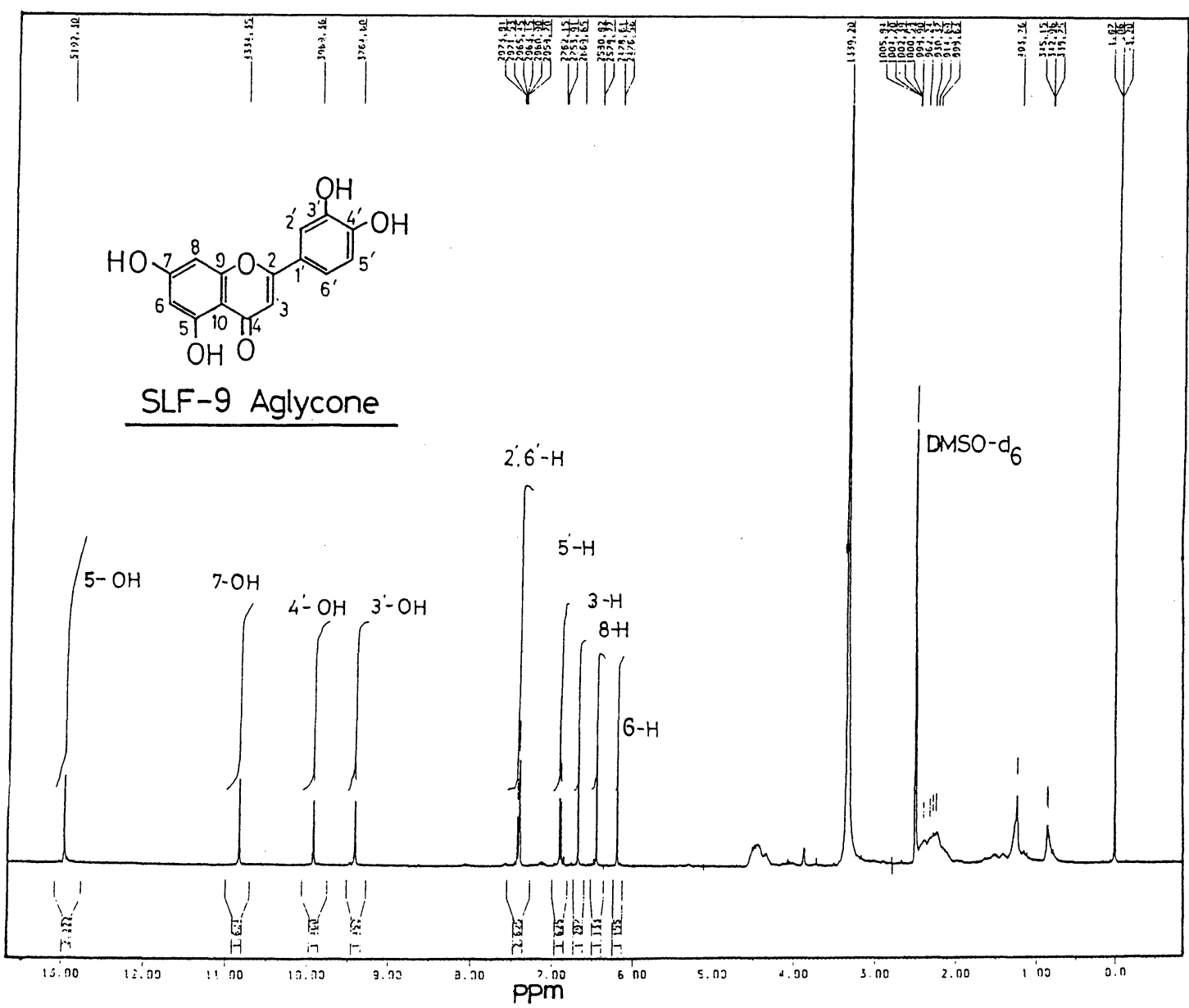

Fig. 1. ${ }^{1} \mathrm{H}-\mathrm{NMR}\left(\mathrm{DMSO}-\mathrm{d}_{6}, 400 \mathrm{MHz}\right)$ spectrum of SLF-9 Aglycone 


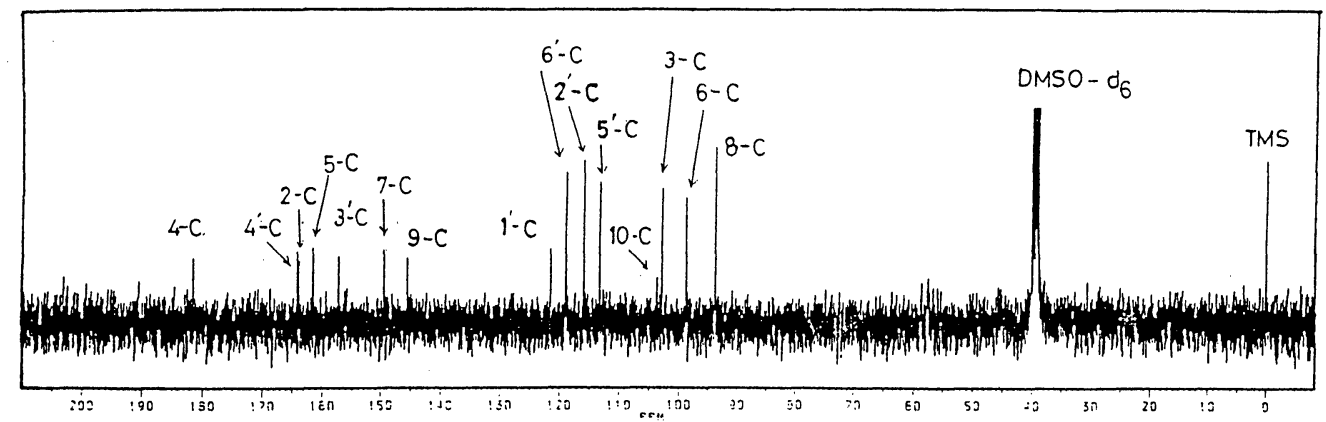

Fig. 2. ${ }^{13} \mathrm{C}-\mathrm{NMR}$ spectrum of SLF-9 Aglycone

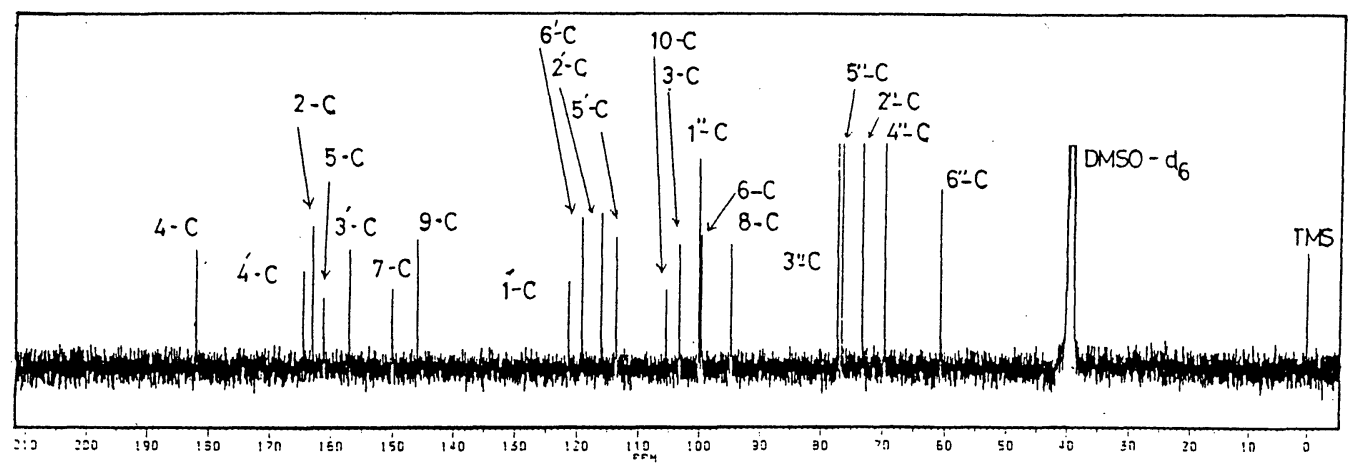

Fig.3. ${ }^{13}$ C-NMR spectrum of SLF-9 Glucoside

Table. $2{ }^{13} \mathrm{C}$-NMR spectra of SLF-9 Aglycone and SLF-9 glucoside (in DMSO- $d_{6}$ )

\begin{tabular}{|c|r|r|}
\hline Carbon No. & Aglycone & Glucoside \\
\hline 2 & $163.86(\mathrm{~s})$ & $162.92(\mathrm{~s})$ \\
3 & $102.84(\mathrm{~d})$ & $103.12(\mathrm{~d})$ \\
4 & $181.62(\mathrm{~s})$ & $181.85(\mathrm{~s})$ \\
5 & $161.44(\mathrm{~s})$ & $161.11(\mathrm{~s})$ \\
6 & $98.79(\mathrm{~d})$ & $99.51(\mathrm{~d})$ \\
7 & $149.66(\mathrm{~s})$ & $150.00(\mathrm{~s})$ \\
8 & $93.80(\mathrm{~d})$ & $94.68(\mathrm{~d})$ \\
9 & $145.70(\mathrm{~s})$ & $145.78(\mathrm{~s})$ \\
10 & $103.67(\mathrm{~s})$ & $105.32(\mathrm{~s})$ \\
1 & $121.47(\mathrm{~s})$ & $121.30(\mathrm{~s})$ \\
2, & $115.98(\mathrm{~d})$ & $115.95(\mathrm{~d})$ \\
3, & $157.25(\mathrm{~s})$ & $156.92(\mathrm{~s})$ \\
4, & $164.08(\mathrm{~s})$ & $164.45(\mathrm{~s})$ \\
5, & $113.34(\mathrm{~d})$ & $113.52(\mathrm{~d})$ \\
6, & $118.95(\mathrm{~d})$ & $119.13(\mathrm{~d})$ \\
$1 "$ & & $99.87(\mathrm{~d})$ \\
2" & & $73.09(\mathrm{~d})$ \\
3" & & $77.14(\mathrm{~d})$ \\
$4 ”$ & & $69.53(\mathrm{~d})$ \\
5" & & $76.37(\mathrm{~d})$ \\
$6 ”$ & & $60.59(\mathrm{t})$ \\
\hline
\end{tabular}

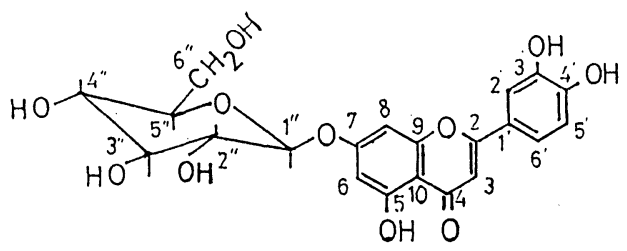

Fig. 4 Structure of SLF-9

体中に、成葉中に存在するフラボノイドが合成され ている事実は生合成の立場から大変興味深く、現在 この点を検討中である。

References

1) F.Preisser, J.Pr.Chem. [i] 32 (1844) 142

2) T.Nakaoki and N.Morita,Yakugaku Zasshi $80(1960) 1473$

3) T.Honma, M.Sawaguchi, H.Kawai, Y.Takahashi and K.Saito, Acta. Soc. Bot. Pol. 54(1985) 403

4) K.Hayashi, "Plants pigments". Yokendo. Ltd., Tokyo. (1980) 176-180

5) T.J.Mabry, K.R.Markham and M.B.Thomas, "The Systematic Identification of Flavonoids", Springer-Verlag. Berlin. (1970) $35-61$ 